\title{
PAUL SCHEERBART AND THE UTOPIA OF GLASS
}

\section{A B S T R A C T}

This paper will consider the architectural writings of the German expressionist writer Paul Scheerbart, focusing on his fascination with glass as an architectural and symbolic material within his writings. I will discuss Scheerbart's architectural treatise Glass Architecture, his novel The Grey Cloth, and related writings on glass architecture. Scheerbart represents an alternative tradition within architectural modernism, which saw glass as a constructive material that represented modernity by exposing structural elements of the building, thus guaranteeing conformation of form to function. Scheerbart, in contrast, considered glass as a bearer of color and multiplier of light, which he saw as capable of transforming the human environment and exercising positive effects on individuals and collectives. He saw light as culture-formative, and glass architecture as the means by which the built environment could maximize modern culture's utopian potential. I also discuss the influence of Scheerbart on the anarchist architect Bruno Taut and on the thinking of Walter Benjamin.
Tyrus Miller

University of California
KEY WORDS

GLASS

ARCHITECTURE

UTOPIA

TRANSPARENCY

PAUL SCHEERBART

BRUNO TAUT 
The name Paul Scheerbart is not common currency among philosophers, and even among architects and historians of architects, he remains a relatively obscure footnote in the story of modernist architecture. Scheerbart is best known as the author of the treatise Glass Architecture from 1914 and as the inspiration and collaborator on Bruno Taut's legendary Glass Pavilion at the Cologne Werkbund exhibition, which included inscriptions about glass architecture composed for the occasion by Scheerbart. Through the exception of its actually having been realized (though of course now known only through various photographs, plans, and descriptions), Taut's Scheerbartian glass pavilion has become the text-book case of the visionary imagination of expressionist architecture, which for the most part remained an artistic and literary practice on paper. After World War I, when the opportunity to build was extremely limited, Taut subsequently formed, under the inspiration of Scheerbart's imaginative architectures, the 'Crystal Chain' (Gläserne Kette) group of artistic and literary correspondents, seeking to develop a utopian conceptual architecture and architectural discourse that might help carry forward the visionary impulse across the present barren period in practice. 'Ideas about architecture,' Taut declared to his correspondents in a chain letter of March 1920, 'have... become more important than architecture itself, and I truly believe that only by proceeding from the point can we reach the root."'1

But who, then, was Paul Scheerbart? Born in 1863 and deceased in 1915, having seen come to pass the technological war he had foretold with irony and dread for many years in his books, Scheerbart enjoyed a certain celebrity status amidst the literary bohemia of Berlin in the late $19^{\text {th }}$ and early $20^{\text {th }}$ century. Scheerbart was the author of scores of fantastic, utopian, science fiction-like novels, short stories, and essays, many of which projected the reconstruction of modern life through technology and architecture. The best-known representation of him is probably a sketch of him by Oskar Kokoschka, published in 1915 in the avant-garde journal Sturm, which renders his face with edgy pen scratches and scrawls and owl-like features, reinforcing Scheerbart's image as an eccentric forerunner and father-figure of the German expressionists. For years an impoverished alcoholic and nocturnal denizen of Berlin's bohemian cafés, transmitted legend has it that Scheerbart brought about his death by refusing to eat in protest of the war.

Given his fantastical work and bohemian lifestyle - in certain respects akin to the Viennese café-writer Peter Altenberg - it is then surprising to read of a personality of the stature of Walter Gropius in 1919 enthusiastically recommending to the artist and writer Hermann Finsterlin that he should 
read Scheerbart for his wisdom and beauty, ${ }^{2}$ and to find a later spokesman of functionalism such as Adolf Behne advancing Scheerbart as (in Iain Boyd Whyte's words) 'a progenitor of the new age of glass architecture."'3 Scheerbart's writings also figured very seriously in Walter Benjamin's early thinking about utopia; in his correspondence with his friend Gershom Scholem, who had given Benjamin a prized copy of Scheerbart's utopian 'asteroid-novel' Lesábendio, Benjamin discusses a philosophical treatise, now lost, on 'true politics,' in which he offers a critique of Scheerbart's novel and seeks to prove that this fictional asteroid society represents the best of worlds. Notably, at the same time, Benjamin was grappling with a critical review of Ernst Bloch's Spirit of Utopia, and he presumably intended to draw upon Scheerbart to offer an alternative conception of utopian politics. Scheerbart would continue to surface intermittently in Benjamin's work as he developed his genealogy of modern architecture from the glass and iron phantasmagorias of $19^{\text {th }}$-century arcades through the rationalist architecture of Corbusier, Gropius, and Mies van der Rohe. In his 1933 essay 'Experience and Poverty,' Benjamin cast Scheerbart's science-fiction novels as a forerunner of a contemporary reduced or 'impoverished' (in a positive sense) culture - a despiritualized culture stripped of the excrescences of Geist - which also included Paul Klee, Bertolt Brecht, and Mickey Mouse. And late in his life, in an unpublished essay, Benjamin brought Scheerbart's post-historical technological fantasies in conjunction with the classic architectural utopia of the late $18^{\text {th }}$ and early $19^{\text {th }}$ centuries, suggesting that Scheerbart -

sometimes seems like the twin brother of [Charles] Fourier. In Fourier's extravagant fantasies about the world of the Harmonians, there is as much mockery of present-day humanity as there is faith in a humanity of the future. It is unlikely that the German utopian knew the work of his French counterpart. But we can be sure that the image of the planet Mercury teaching the Harmonians their mother-tongue would have delighted Paul Scheerbart. ${ }^{4}$

In a pathbreaking article published in The Architectural Review in 1959, the architectural historian Reyner Banham would look back on the nowcanonical history of modern architecture and argue that it was necessary to bring Scheerbart's visionary line back into the conversation, from which it had been marginalized. '[I]f one applies to [Scheerbart] the normal test for missing pioneers, that of prophecy uttered in the right ears at the right time,' Banham writes -

he scores more heavily than many other writers of his day. Not only were his architectural writings known and in varying degrees influential 
among the generation of Gropius and Mies van der Rohe, but at a time when many spoke of steel and glass, he also spoke of water as the natural complement of glass, of the need to temper the white glare of light through glass by the use of contoured tinting, he spoke of America as the country where the destinies of glass architecture would be fulfilled, and he spoke of the propriety of the 'Patina of bronze' as a surface. In other words, he stood closer to the Seagram Building than Mies did in $1914 .^{5}$

Banham suggests - as have other later architectural historians such as Rosemarie Haag Bletter and Detlef Mertins - that Scheerbart initiates a nonrationalist, visionary modernist counter-tradition in architecture centered on glass and colored light. Extending through the Activism of Bruno Taut into the technology-inspired light-motion experiments of László MoholyNagy, Ludwig Hirschfeld-Mack, and Zdeněk Pešánek, Scheerbart posed an alternative aesthetic within architectural modernism, which came to see glass as a 'rational' constructive material that represented modernity by exposing the structural elements of the building, guaranteeing honest, unadorned conformation of form to function. Scheerbart, in contrast, considered glass in terms of its experiential qualities as a bearer of color and multiplier of light, which he saw as capable of enlivening and transforming the human environment and exercising positive moral and emotional effects on individuals and collectives. He saw light as culture-formative, and glass architecture as the means by which the built environment could maximize this potential for new culture. As Detlef Mertins concludes, 'for Scheerbart and Taut, glass architecture created a new environment for new kinds of experience, for a new subjectivity. The Glass House provided an immersive artistic environment - a total work of art integrating glass construction, glass art and mosaics - which induced an altered state of consciousness as the subject dissolved empathetically to be at one with the world." "'6

This is the point I want most strongly to emphasize, and which makes a consideration of Scheerbart and his utopia of glass of more than art-historical interest: in this tradition of architectural thinking and, to some extent, practice as well, architecture is considered not simply as a way of containing and articulating various social functions, but rather as a kind of phenomenologicalsensory technology akin to media like cinema, as a kind of materialized and enactable correlate of various actual and possible experiences. In this regard too, the distinction between the imaginary, fictional, and speculative architectures in Scheerbart's novels or in the letters of Taut's Crystal Chain group and actual 
avant-garde buildings such as Taut's Glass Pavilion are not essential, but represent merely different sorts of materialization of common experiments in potential modes of human thought and feeling. In fact, the eccentric and fragmentary archive of materials related to this tradition - mostly composed of photographs, plans, drawings, and texts - raises interesting general questions about the relationships between built space, phenomenological experience, language, and graphic traces in architecture broadly, not just in this particular lineage.

With this conceptual background in mind, I will now turn briefly to two texts by Scheerbart, the first a novel about glass architecture entitled, in full, The Grey Cloth and Ten Percent White: A Ladies Novel, published in 1914, and, from the same year, his treatise Glass Architecture, which together reveal a number of aspects of his utopian aesthetic of glass architecture. The novel The Gray Cloth and Ten Percent White centers upon the adventurous life of a Swiss architect Herr Edgar Krug and his wife, Clara. Scheerbart's novel is episodic, serving mostly as a vehicle for a series of witty, imaginative, descriptive vignettes of the extravagant glass constructions of the architectural master and the futuristic technologies of transportation and communication at his disposal. At an exhibition space designed by Krug on Lake Michigan in Chicago, he meets his future wife, one of the exhibited artists. Scheerbart first describes the interaction of the colored glass with the water of the lake:

One saw the very colorful reflection of the palaces in Lake Michigan. Like hummingbirds, dragonflies, and butterflies the countless colors flickered along the moving waves of the lake. And the full moon glowed. It too was reflected in the water. Several airplanes travelled over the lake, letting their colorful floodlights frolic.

'A very colorful picture!' said Herr Krug. And he lit himself a cigarette.?

The title of the novel refers to the modernistic, austere garment that his future wife Clara is wearing when Herr Krug first encounters her among his colorful glass exhibition hall, and which subsequently becomes part of their marriage contract:

Herr Krug was extremely surprised by the appearance of Fräulein Clara Weber. The lady wore a simply gray garment with ten-percent white trim. Herr Krug was immediately enchanted by this outfit and said so, again apologizing to Miss Amanda for not finding her colorful clothing beautiful - since it did not work well with his glass walls - for in Herr Krug's view only a gray outfit with ten percent white suited his glass walls. $(G C, 8)$ 
Bound by their humorously eroticized aesthetic encounter, Edgar and Clara fall precipitously in love, and resolve to marry. Edgar, however, demands of his wife that she relinquish colorful clothing and wear only grey with ten percent white, so that she will be forever in harmony with his colorful glass architecture, which the novel portrays him constructing all over the world, from Antarctica to Ceylon to Central Asia to Cyprus and North Africa. Through the doubts and objections of his wife and other women characters in the novel - the gender politics of the book are anything but straightforwardly celebratory of the patriarchal artistic genius, caught up in his glass world Scheerbart ironizes Edgar's fetishistic obsession with materials and colors and his temperamental monomania, as in this scene:

Desperately, Edgar said to his wife:

'Look! I could assemble the biggest thing in the world here. The people here are excited about glass architecture. And over and over again I find that wherever on earth there is excitement there is never any money. That is a sorrow.'

'But be that as it may,' consoled Frau Clara, 'you must build on all those sites that have enough money available.'

'There can never be enough built!' shouted Mr. Edgar, and he left the room.

'There is something insatiable about my husband,' Miss Clara said to her chambermaid. $(G C, 80)$

Yet Clara remains faithful both to Edgar and to her sartorial pledge not to compete in color with the glass-produced colored environments of her husband's practice. What was originally a bizarre and authoritarian demand on her, eventually becomes a freely chosen constraint on her fashion choices as she comes to appreciate her inclusion in the endlessly renewed worlds of color, light, and sounds that her husband designs using his favored material and its kaleidoscopic architectonic forms, spatial transformations, and patterned light.

Scheerbart's treatise Glass Architecture is the discursive counterpart to The Grey Cloth's narrative fantasia. Written in a series of one-hundred and eleven manifesto-like short paragraphs - and published under the imprint of the Sturm Verlag, which was closely associated with the expressionistic avant-garde in art and poetry - the section titles veer between the practical ('Magnesite and the perfect floor covering for the house,' 'Glass fibres in applied art,' 'Glass mosaic and reinforced concrete,' 'Vanquishing vermin') and the speculative ('The beauty of the Earth, when glass architecture is everywhere,' 'Aircraft with coloured lights,' 'Airports as glass palaces,' 'The transformation of the 
Earth's surface,' 'A composed and settled nation, when glass architecture comes'). Similarly, at the level of content, Scheerbart's text is a curious hybrid of practical observations and utopian fantasy. For example, he has prescient remarks on the use of glass bricks as a building material:

So-called glass bricks make a wall material which may well become an interesting speciality of glass architecture. . . Everything fire-proof and transparent is aesthetically justifiable as a wall material. Glass bricks should make many iron skeletons superfluous. ${ }^{8}$

He also perceived that the greater possibilities for shaping that glass and iron materials allow would also shift the hierarchy of relations between the building's silhouette and the groundplan. As the building shape becomes increasingly independent of its groundplan, the groundplan becomes much less determinative than when vertical walls were a near inevitability of the building material ( $G A$ 53). Scheerbart drew a number of implications from this, ranging from an individual's experience of a room, where, for example, curved walls and dome-effects can change the experience of horizontal and vertical orientations in space, to the near-cosmic, in which the use of glass, colored light, and aviation frees human habitation from its Earth-bound weight and gravity.

In other sections, Scheerbart evokes an acute phenomenological sense of his imagined technologically modified environments, as in this passage on ventilators, which captures the sensory oddity of the air-conditioned glass spaces we have since become accustomed to live and work in:

It will seem very natural that ventilators should have a principal part to play in a glass house, and will supplant everything window-like. When I am in my glass room, I shall hear and see nothing of the outside world. If I long for the sky, the clouds, woods and meadows, I can go out or repair to an extra-veranda with transparent glass panes. ( $G A$ 51)

The psychological effects of colored light on dwellers would, in Scheerbart's view, be another aspect of the expansion of glass architecture to all domains of habitation. Like the colored lamps and windows of earlier sacred architecture, colored glass would introduce a spiritualizing influence into the modern house. 'Glass architecture,' he writes,' makes homes into cathedrals, with the same effects' (GA 87). It will lead to a kind of utopian domestication of the desire for new places that tourism fulfills, since all the modern demand for sensation and novelty of experience can be satisfied by the kaleidoscopic glass-light machine that everyone will live in: 'When home life has reached the stage where even the wildest fancies appear to be realized, the longing for something different ceases; 
people will travel only to learn about a particular type of glass art and possibly to bring it home - to be able to reproduce it in a similar design' (GA 88).

For Scheerbart, the material to be replaced by glass architecture is especially brick, the extensive use of which has led to the dark, colorless, unhygienic, and militarily vulnerable cities of the early twentieth-century: 'The present brick 'culture' of the city, which we all deplore, is due to the railway. Glass architecture will only come if the city as we know it goes. It is completely clear to all those who care about the future of our civilization that this dissolution must take place' (GA 84). Bruno Taut would soon take up and elaborate these propositions of Scheerbart in his post-World War I, anti-urban, anarchist architectural fantasies such as Alpine Architecture (1919) and The Dissolution of the Cities (1920). 'The face of the earth would be much altered,' Scheerbart writes, 'if brick architecture were ousted everywhere by glass architecture. It would be as if the earth were adorned with sparkling jewels and enamels. .. We should then have a paradise on earth, and no need to watch in longing expectation for the paradise in heaven' (GA 38). He concluded that a new glass culture would arise that would be, at once, a return to nature from the alienated world of the $19^{\text {th }}$-century industrial city, and a transcendence of nature through its technological transfiguration.

As Detlef Mertins summarizes:

Glass architecture served to designate a world that was a compound - 100 per cent human and 100 per cent natural - the result of natural evolution and technological development rolled into one. In this world, it was understood that technologies were transparent when their technical forms were perfected so as to express their immanent logics... The geometric perfection of their morphology gave them the character of a crystal, while their capacity to perform functions and do work gave them the character of living organisms. ${ }^{9}$

Of course, the optimism with which in 1914 Scheerbart greeted the exponential unfolding of modern technology, embodied for him by his utopia of glass architecture, is ironic, given the outbreak of the First World War only a few months after the publication of Scheerbart's treatise and the author's own death, in torment over the destructive conflict gripping Europe, the following year. I will conclude by allowing this irony to resound in Scheerbart's pronouncement in his penultimate paragraph of Glass Architecture: 'We are not at the end of a cultural period-but at the beginning. We still have extraordinary marvels to expect from technics and chemistry, which should not be forgotten. This ought to give us constant encouragement' ( $G A 90)$. 
Letter of Bruno Taut, 13 March 1920, in The Crystal Chain Letters: Architectural Fantasies by Bruno Taut and His Circle, ed. and trans. Iain Boyd Whyte (Cambridge, Massachusetts: The MIT Press, 1985), 73.

Iain Boyd Whyte, "Introduction," in The Crystal Chain Letters, 8.

Iain Boyd Whyte, Bruno Taut and the Architecture of Activism (Cambridge: Cambridge University Press, 1982), 187.

Walter Benjamin, Selected Writings, Volume IV: 1938-1940, eds. Howard Eiland and Michael W. Jennings (Cambridge, MA: The Belknap Press of Harvard University Press, 2002), 387-88. Reyner Banham, “The Glass Paradise," in A Critic Writes: Essays, eds. Mary Banham et al (Berkeley and Los Angeles: University of California Press, 1996), 38.

Detlef Mertins, "Glass Architecture" in Modernity Unbound: Other Histories of Architectural Modernity (London: Architecture Association, 2011), 17-18. Stuart (Cambridge, Massachusetts: The MIT Press, 2001), 7. Paul Scheerbart, Glass Architecture, in Glass! Love!! Perpetual Motion!!!, eds. Josiah McElheny and Christine Burgin (Chicago: University of Chicago Press, 2014), 45. 
Banham, Reyner. “The Glass Paradise.” In A Critic Writes: Essays, eds. Mary Banham et al, 38. Berkeley and Los Angeles: University of California Press, 1996.

Benjamin, Walter. Selected Writings, Volume IV: 1938-1940, eds. Howard Eiland and Michael W. Jennings, 387-388. Cambridge, MA: The Belknap Press of Harvard University Press, 2002. Mertins, Detlef. "Glass Architecture.” In Modernity Unbound: Other Histories of Architectural Modernity .London: Architecture Association, 2011.

Scheerbart, Paul. The Grey Cloth: Paul Scheerbart's Novel on Glass Architecture, trans. John A. Stuart .Cambridge, Massachusetts: The MIT Press, 2001.

Scheerbart, Paul. Glass Architecture, in Glass! Love!! Perpetual Motion!!!, eds. Josiah McElheny and Christine Burgin .Chicago: University of Chicago Press, 2014.

Taut, Bruno. "Letter of Bruno Taut, 13 March 1920" In The Crystal Chain Letters: Architectural Fantasies by Bruno Taut and His Circle, ed. and trans. Iain Boyd Whyte, 7.Cambridge, Massachusetts: The MIT Press, 1985.

Whyte, Iain Boyd. Bruno Taut and the Architecture of Activism .Cambridge: Cambridge University Press, 1982. 
Kompletno istraživanja objavljeno je u knjizi The indispensable excess of the aesthetics: evolution of sensibility in nature (Neizostavni višak estetike: Evolucija senzibiliteta u prirodi, Lexington 2015).

KLJUČNE REČI: EVOLUTIVNA ESTETIKA, DARVIN, BIOSEMIOTIKA, ZOO-POETIKA, AESTHESIS, ZOO-ESTETIKA, EVOLUCIJA

\section{OBECANJE MEDIJSKE ARHEOLOGIJE Nadežda Čačinovič}

Medijska arheologija nudi novi i neophodan alat za suočavanje sa mnoštvom fenomena koje tako neselektivno - anahrono ili na druge načine - prepoznajemo kao umetnost i klasifikujemo kao umetnička dela. Rad pokušava da naglasi razliku u poređenju sa srodnim gledištim: teorije kulturne transmisije, materijalnosti kulture, logike estetskih režima itd. Moglo bi se nazvati "mediji pre medija" (i prati Kitlera (Kittler)) ili kopati sa Zilinskim u "Duboko vreme medija" (Deep Time of the Media) sa dobrom vezom prema "istoriji pristupa čula" ili ići pravo sa Jusi Parikom i Erki Huhtamom (Jussi Parikka, Erkki Huhtamo) i koristiti "medijsku arheologiju”: ali je uvek priznanje protejske prirode umetnosti i arhitekture.

KLJUČNE REČI: MATERIJALNOST KULTURE, ISTORIJA ČULA, MEDIJI, KULTURNA TRANSMISIJA

\section{FORMA I ZNAČENJE U ARHITEKTONSKOJ TEORIJI Jale Nejdet Erzen}

Često je arhitektonska teorija bilo jasno izražena propisanim stavovima o tome šta bi arhitektura trebalo da bude, pre nego stavovima formulisanim od istorijskih iskustava i primera arhitekture. U ovom radu ću pokušati da ponudim čitanje arhitektonske forme gledajući istorijski primer iz klasične otomanske arhitekture i savremene primere, pokazujući kako različite arhitekture tretiraju formu. U primerima Sinanove arhitekture, simboli su istraživani u odnosu na kretanje, urbani sklop, religiju i moć. Ideja je da će ova analiza ponuditi razumevanje značaja arhitekture u okvirima ljudskog iskustva i urbanog konteksta kojii dopire izvan strukture i funkcije.

KLJUČNE REČI: ARHITEKTURA, SINAN, FORMA, ZNAČENJE, STRUKTURA, TELESNI ODNOSI

\section{POL ŠIRBART I UTOPIJA OD STAKLA}

\section{Tyrus Miller}

Ovaj rad će razmotriti arhitektonske spise nemačkog ekspresionističkog pisca Pola Širbarta (Paul Scheerbart), sa fokusom na njegovoj fascinaciji staklom kao arhitektonskim i metaforičkim materijalom. Diskusija je o Širbartovom arhitektonskom traktatu Arhitektura stakla (Glass Architecture), njegovom romanu Siva tkanina (The Grey Cloth) i srodnim tekstovima o arhitekturi stakla. Širbart predstavlja alternativnu tradiciju unutar arhitektonskog modernizma, koja gleda na staklo kao na konstruktivan materijal koji predstavlja modernost kroz izlaganje strukturalnih elemenata, takođe u službi komfor forme prema funkciji. Širbart, nasuprot tome, smatra staklo nosiocem boje i multiplikatora svetlosti, koje je video kao sposobnog da transformiše čovekovu okolinu i ostvari pozitivne efekte na pojedince i kolektive. On je video svetlost kao kulturnoformativnu, a arhitekturu stakla kao sredstvo kojim izgrađeno okruženje može da poveća moderni kulturalni utopijski potencijal. Takođe, ukratko ću razmotriti i uticaj Širbarta na anarhističkog arhitektu Bruna Tauta (Bruno Taut) i na razmišljanja Valtera Benjamina (Walter Benjamin). 